\title{
Protease-cleaved Iron-Transferrin Augments Oxidant-mediated Endothelial Cell Injury via Hydroxyl Radical Formation
}

\author{
Rachel A. Miller and Bradley E. Britigan \\ Research Service and Department of Internal Medicine, Veterans Affairs Medical Center, Iowa City, Iowa 52246; and Department of \\ Internal Medicine, The University of Iowa College of Medicine, Iowa City, Iowa 52242
}

\begin{abstract}
Previous work has shown that the Pseudomonas-derived protease, pseudomonas elastase (PAE), can modify transferrin to form iron complexes capable of catalyzing the formation of hydroxyl radical ( $\cdot \mathrm{OH})$ from neutrophil (PMN)derived superoxide $\left(\cdot \mathrm{O}_{2}^{-}\right)$and hydrogen peroxide $\left(\mathrm{H}_{2} \mathrm{O}_{2}\right)$. As the lung is a major site of Pseudomonas infection, the ability of these iron chelates to augment oxidant-mediated pulmonary artery endothelial cell injury via release of ${ }^{51} \mathrm{Cr}$ from prelabeled cells was examined. Diferrictransferrin previously cleaved with PAE significantly enhanced porcine pulmonary artery endothelial cell monolayer injury from 2.3-6.3 to 15.8-17.0\% of maximum, resulting from exposure to $\mathrm{H}_{2} \mathrm{O}_{2}$, products of the xanthine/xanthine oxidase reaction, or PMA-stimulated PMNs. Iron associated with transferrin appeared to be responsible for cell injury. Spin trapping and the formation of thiobarbituric acid-reactive 2-deoxyribose oxidation products demonstrated the production of $\cdot \mathbf{O H}$ in this system. The addition of catalase, dimethyl thiourea, and the hydrophobic spin trap, $\alpha$-phenyl- $n$-terbutyl-nitrone, offered significant protection from injury (27.8$58.2 \%$ ). Since sites of Pseudomonas infection contain other proteases, the ability of porcine pancreatic elastase and trypsin to substitute for PAE was examined. Results were similar to those observed with PAE. We conclude $\cdot \mathrm{OH}$ formation resulting from protease alteration of transferrin may serve as a mechanism of tissue injury at sites of bacterial infection and other processes characterized by increased proteolytic activity. (J. Clin. Invest. 1995. 95:2491-2500.) Key words: Pseudomonas - spin trap • neutrophil • inflammation • elastase
\end{abstract}

\section{Introduction}

Sites of Pseudomonas aeruginosa infection are notable for an intense infiltration of neutrophils (PMNs) and can exhibit marked tissue damage. A variety of PMN- and bacteria-derived secretory products, particularly proteases, have been suggested to play a role in tissue injury (1-8). Neutrophil oxidant formation has also been implicated as an important contributor to tissue injury at sites of inflammation under a variety of conditions (9-12). However, the role of these PMN-derived products

Address correspondence to Rachel A. Miller, MD, Department of Internal Medicine, The University of lowa, 200 Hawkins Dr., SW34 GH, Iowa City, IA 52242. Phone: 319-356-7228; FAX: 319-356-4600.

Received for publication 10 October 1994 and in revised form 26 January 1995.

The Journal of Clinical Investigation, Inc.

Volume 95, June 1995, 2491-2500 in $P$. aeruginosa-mediated tissue injury has not been as extensively investigated.

Neutrophil-derived superoxide $\left(\mathrm{O}_{2}^{-}\right)$and hydrogen peroxide $\left(\mathrm{H}_{2} \mathrm{O}_{2}\right)$ are only moderately reactive oxidants. In the presence of an exogenous iron catalyst, $\cdot \mathrm{O}_{2}^{-}$and $\mathrm{H}_{2} \mathrm{O}_{2}$ can react to form the highly cytotoxic $\cdot \mathrm{OH}$ via the Haber-Weiss reaction (13). A number of in vitro and in vivo studies have suggested that $\cdot \mathrm{OH}$ may be one of the reactive oxygen species involved in tissue injury at sites of inflammation (14). Because PMNs do not possess an endogenous catalytic iron source for $\cdot \mathrm{OH}$ generation, in order for this species to be produced in vivo, an exogenous catalytic iron complex must be present $(3,15)$. In vivo, almost all extracellular iron is tightly bound to host ironbinding proteins $(16-18)$.

Transferrin, a 76,000-80,000-D protein, is the principal iron-binding protein in serum and is present in lower concentrations at mucosal surfaces (18). The iron-binding protein, lactoferrin, provides the majority of the iron-chelating capacity at mucosal surfaces although transferrin is also present (18). When bound to either of these proteins, iron cannot act as a -OH catalyst (19-22). This property may allow transferrin and lactoferrin to function as inhibitors of oxidant-mediated tissue injury $(23,24)$.

A number of PMN- and bacteria-derived proteases cleave transferrin and/or lactoferrin into smaller protein fragments (25-30). We have demonstrated previously that a $P$. aeruginosa-derived elastase (pseudomonas elastase [PAE]) ${ }^{1}$ cleaves diferrictransferrin (Fe-transferrin or FeTF) into smaller protein fragments able to catalyze $\cdot \mathrm{OH}$ formation (31). Fe-transferrin cleaved with human neutrophil elastase (HNE), trypsin, and pseudomonas alkaline protease did not catalyze detectable amounts of $\cdot \mathrm{OH}$ formation (31). Attesting to the potential clinical relevance of these findings, we consistently detected transferrin cleavage products in bronchoalveolar lavage (BAL) specimens from $P$. aeruginosa-infected cystic fibrosis patients but not in normal individuals (32).

Microvascular endothelial cells are among the cells which appear to be injured at sites of $P$. aeruginosa infection such as the lung (33-36). These cells are also well recognized for their susceptibility to oxidant-mediated injury (37). Therefore, we examined the possibility that protease-cleaved Fe-transferrin could augment oxidant-mediated pulmonary artery endothelial cell injury via $\cdot \mathrm{OH}$ formation. Here we report the results of these studies and discuss them as a potential mechanism of inflammatory tissue injury.

1. Abbreviations used in this paper: BAL, bronchoalveolar lavage; DMTU, dimethyl thiourea; DTPA, diethylenetriaminepentaacetic acid; EPR, electron paramagnetic resonance; FeTF or Fe-transferrin, diferrictransferrin; HNE, human neutrophil elastase; PAE, pseudomonas elastase; PBN, $\alpha$-phenyl- $n$-terbutyl-nitrone; 4-POBN, 4-pyridyl $N$-t-butylnitrone; PPE, porcine pancreatic elastase; TBA, thiobarbituric acid. 


\section{Methods}

Reagents. PAE (64.7 U/mg protein) was obtained from Nagase Biochemicals (Tokyo, Japan). Porcine pancreatic elastase (PPE) (70 U/ $\mathrm{mg}$ solid, $120 \mathrm{U} / \mathrm{mg}$ protein $)$, trypsin $(12,600 \mathrm{U} / \mathrm{mg}$ solid, $13,000 \mathrm{U} /$ $\mathrm{mg}$ protein), apo-transferrin, Fe-transferrin, catalase, $\mathrm{CuZn}$-superoxide dismutase (SOD), $\alpha$-phenyl- $n$-terbutyl-nitrone (PBN), 4-pyridyl $N$-tbutyl-nitrone (4-POBN), diethylenetriaminepentaacetic acid (DTPA), phorbol myristate acetate (PMA), 2-deoxyribose, thiobarbituric acid (TBA), hypoxanthine, and xanthine were all obtained from Sigma Chemical Co. (St. Louis, MO). Other agents were purchased as follows: xanthine oxidase was purchased from Boehringer-Mannheim Biochemicals (Indianapolis, IN); dimethyl sulfoxide (DMSO) from Fisher Scientific Co. (Fairlawn, NJ); dimethyl thiourea (DMTU) from Aldrich Chemical Co. (Milwaukee, WI); and ethanol from Aaper Chemical Co. (Shelbeysville, KY).

Protease cleavage of apotransferrin and diferrictransferrin. Apotransferrin or diferrictransferrin mixtures $(20 \mathrm{mg} / \mathrm{ml})$ suspended in Hanks' balanced salt solution without phenol red and with calcium chloride ( $0.185 \mathrm{~g} /$ liter) and magnesium sulfate (0.098 $\mathrm{g} /$ liter) (HBSS, University of Iowa Cancer Facility, Iowa City, IA) were incubated in the presence of PAE (20 $\mu \mathrm{g} / \mathrm{ml})$, PPE $(200 \mu \mathrm{g} / \mathrm{ml})$, or trypsin $(50 \mu \mathrm{g} /$ $\mathrm{ml}$ ) for $48-72 \mathrm{~h}$ at $37^{\circ} \mathrm{C}$. These conditions were chosen based on our previous data (31) indicating that they produced optimal cleavage of the protein. Control samples containing apo- or diferrictransferrin alone or each protease alone were incubated in parallel. Extent of protease cleavage was assessed by SDS-PAGE (see below).

SDS-PAGE. Transferrin preparations of interest were solubilized by boiling in Laemmli solubilizing buffer (38) containing 2-mercaptoethanol (1\%) for $5 \mathrm{~min}$. Samples (4.4-8.7 $\mu \mathrm{g}$ protein/lane) were electrophoresed ( $150 \mathrm{~V}$ hours) into a $14 \%$ polyacrylamide minigel after which the proteins were silver stained (Accurate Chemical \& Scientific Corp., Westbury, NY).

Cell culture. Pulmonary artery endothelial cells were obtained from porcine pulmonary artery using techniques described by Shasby et al. (39). For ${ }^{51} \mathrm{Cr}$ release experiments (see below), endothelial cell monolayers from passes 5-9 were plated at a concentration of $3.75 \times 10^{4}$ cells per well in 48-well tissue culture plates (Costar Corp., Cambridge, MA) in $0.5 \mathrm{ml}$ medium 199 (University of Iowa Cancer Facility) with $10 \%$ serum, basal medium amino acids, basal minimal essential vitamins, $2 \mathrm{mM}$ I-glutamine, and $10 \mathrm{U} / \mathrm{ml}$ penicillin/streptomycin (Gibco Laboratories, Grand Island, NY). The plates were then incubated at $37^{\circ} \mathrm{C}, 5 \% \mathrm{CO}_{2}$ for $4-5 \mathrm{~d}$. For spin trapping experiments, confluent monolayers of porcine pulmonary artery endothelial cells were generated on microcarrier beads (Cytodex 3; Pharmacia LKB Biotechnology, Piscataway, $\mathrm{NJ})$ using previously described methods $(39,40)$. Multiple cell lines (passages 5-9) were used for these studies and were cultured for 2-3 d after confluence. Before use, cell coated beads were washed free of culture media with HBSS three times and resuspended in HBSS at $25 \%$ ( vol $/ \mathrm{vol})$ microcarrier beads $\left(0.5-1.0 \times 10^{7} \mathrm{cells} / \mathrm{ml}\right)$. For all methods involving endothelial cells, each experiment was performed with the transferrin cleavage products and the appropriate paired controls to account for the variability in injury susceptibility of each cell line due to the length of time it was in passage.

Human PMN isolation. PMNs were separated from whole blood as previously described (41). Briefly, whole blood was Dextran sedimented, and the leukocyte-rich layer was centrifuged through FicollHypaque. Erythrocyte contamination of the PMN-containing fractions was removed by hypotonic lysis. Final PMN suspensions ( $>95 \%$ purity) were maintained at $4^{\circ} \mathrm{C}$ in HBSS and used within $2 \mathrm{~h}$.

${ }^{5 l}$ Chromium release assay. This assay was performed as described previously with slight modification (11). For experiments in which protease cleaved $\mathrm{Fe}$ (apo)-transferrin $(4 \mathrm{mg} / \mathrm{ml})$ was used, endothelial cells were allowed to preincubate for $30 \mathrm{~min}$ in the presence of these compounds or controls (media alone) before the addition of oxidant agents $\left(\mathrm{H}_{2} \mathrm{O}_{2}\right.$, xanthine/xanthine oxidase, or PMA-stimulated PMNs). Antioxidant compounds and $\cdot \mathrm{OH}$ scavengers $(500 \mathrm{U} / \mathrm{ml}$ catalase, 50 $\mu \mathrm{M}$ DMTU, $300 \mathrm{U} / \mathrm{ml}$ SOD, $140 \mathrm{mM}$ DMSO, $10 \mathrm{mM}$ PBN, $10 \mathrm{mM}$
4-POBN) were added before the 30-min preincubation in selected experiments. The concentration of oxidant used was titrated to produce no more than $15 \%$ of maximum ${ }^{51} \mathrm{Cr}$ release alone, generally $\mathrm{H}_{2} \mathrm{O}_{2}(5-10$ $\mu \mathrm{M})$, xanthine $(100 \mu \mathrm{M}) / \mathrm{xanthine}$ oxidase $(0.1 \mathrm{U} / \mathrm{ml})$, and PMA $(100$ $\mathrm{ng} / \mathrm{ml})$ stimulated PMNs $\left(10^{3}-10^{5}\right.$ cells $\left./ \mathrm{ml}\right)$. Spontaneous release was measured as the amount of ${ }^{51} \mathrm{Cr}$ release over $4 \mathrm{~h}$ by cells incubated in HBSS alone and was a mean of $20.7 \%$ of maximum release for all experiments performed. Results of each experiment are expressed as the mean specific ${ }^{51} \mathrm{Cr}$ release of triplicate samples where specific ${ }^{51} \mathrm{Cr}$ release is defined as:

(test well ${ }^{51} \mathrm{Cr} \mathrm{cpm}-$ spontaneous release ${ }^{51} \mathrm{Cr} \mathrm{cpm}$ ) (maximum release ${ }^{51} \mathrm{Cr} \mathrm{cpm}-$ spontaneous release ${ }^{51} \mathrm{Cr} \mathrm{cpm}$ ).

Formation of TBA-reactive 2-deoxyribose oxidation products. The assay was performed using previously described methods $(31,42,43)$. Briefly, 1-ml reaction mixtures were prepared using hypoxanthine (2 $\mathrm{mM})$ and 2-deoxyribose (5 mM), with or without iron chelates such that the final iron concentration was $25 \mu \mathrm{M}$. Xanthine oxidase (15 $\mathrm{mU} / \mathrm{ml}$ ) was added, and the mixture was incubated at $37^{\circ} \mathrm{C}$ (rotating incubator) for $15 \mathrm{~min}$. The mixture was then added to $0.5 \mathrm{ml}$ of $1 \%$ TBA and $1.0 \mathrm{ml}$ of $6 \%$ tricheoroacetic acid (TCA) and heated to $100^{\circ} \mathrm{C}$ for $10 \mathrm{~min}$. The protein was pelleted $(1,000 \mathrm{~g}, 5 \mathrm{~min})$, and the absorbance at $532 \mathrm{~nm}$ of the supernatant was determined spectrophotometrically (model DW-2000; SLM-AMINCO, Urbana, IL).

Spin trapping. Spin trapping was performed using the previously described methods (11). $\mathrm{H}_{2} \mathrm{O}_{2}(10 \mu \mathrm{M})$ or PMA-stimulated PMNs $\left(10^{5}\right.$ cells $/ \mathrm{ml})$ were added to a solution containing HBSS, DTPA $(0.1 \mathrm{mM})$, 4-POBN ( $20 \mathrm{mM}$ ), ethanol ( $1 \%)$, with or without the protease cleavage products or controls. The reaction mixture was transferred to a flat quartz electron paramagnetic resonance (EPR) cell, and the EPR spectrum was determined with signal averaging at $25^{\circ} \mathrm{C}$ using an EPR spectrometer (model ESP 300; Bruker, Karlsruhe, Germany). EPR spectrometer settings were: microwave power $20 \mathrm{~mW}$, modulation frequency $100 \mathrm{kHz}$, modulation amplitude 0.941 Gauss (G), time constant $0.164 \mathrm{~s}$, and the gain $5.0 \times 10^{5}$. In this system, detection of the $\cdot \mathrm{OH}$-derived spin adduct, 4-POBN $/ \cdot \mathrm{CHOHCH}_{3}\left(A_{\mathrm{N}}=15.5 \mathrm{G}, A_{\mathrm{H}}=2.6 \mathrm{G}\right)(15)$, is the expected result when $\cdot \mathrm{OH}$ is formed. Similar experiments were also performed in the presence of $25 \%$ porcine pulmonary artery endothelial cells on microcarrier beads in HBSS. All buffers were routinely treated with chelating resin (Sigma Chemical Co.) to reduce the presence of adventitious iron. The EPR spectra shown are representative of experiments performed a minimum of three times.

Statistical analysis. A paired ANOVA test was performed for all analyses of data in groups of three or more. A two-tailed $t$ test was used for all groups of two. Results were considered significant at $P<0.05$.

\section{Results}

Is oxidant-mediated endothelial cell injury augmented by PAEcleaved Fe-transferrin? Given the susceptibility of endothelial cells to oxidant-mediated injury, the ability of PAE-cleaved Fetransferrin to augment this injury was examined. Fe-transferrin cleavage was confirmed by SDS-PAGE demonstrating the appearance of two or more bands of lower molecular weight than that of the Fe-transferrin standard, consistent with our previous results (31). Endothelial cell injury was initially studied in the presence of sublethal concentrations of $\mathrm{H}_{2} \mathrm{O}_{2}$ and products of the xanthine/xanthine oxidase reaction. As quantitated by the release of ${ }^{51} \mathrm{Cr}$ from prelabeled endothelial cells, $10 \mu \mathrm{M} \mathrm{H}_{2} \mathrm{O}_{2}$ resulted in a $6.3 \%{ }^{51} \mathrm{Cr}$ release of maximum (Fig. $1 \mathrm{~A}$ ). The addition of $10 \mu \mathrm{M} \mathrm{H}_{2} \mathrm{O}_{2}$ to paired endothelial cell monolayers which had been preincubated for $30 \mathrm{~min}$ in the presence of PAE-cleaved Fe-transferrin resulted in a $16.4 \%$ specific ${ }^{51} \mathrm{Cr}$ release (Fig. $1 A$ ). This was a statistically significant difference relative to that seen with $\mathrm{H}_{2} \mathrm{O}_{2}$ alone $(n=15, P<0.01)$. Cells 

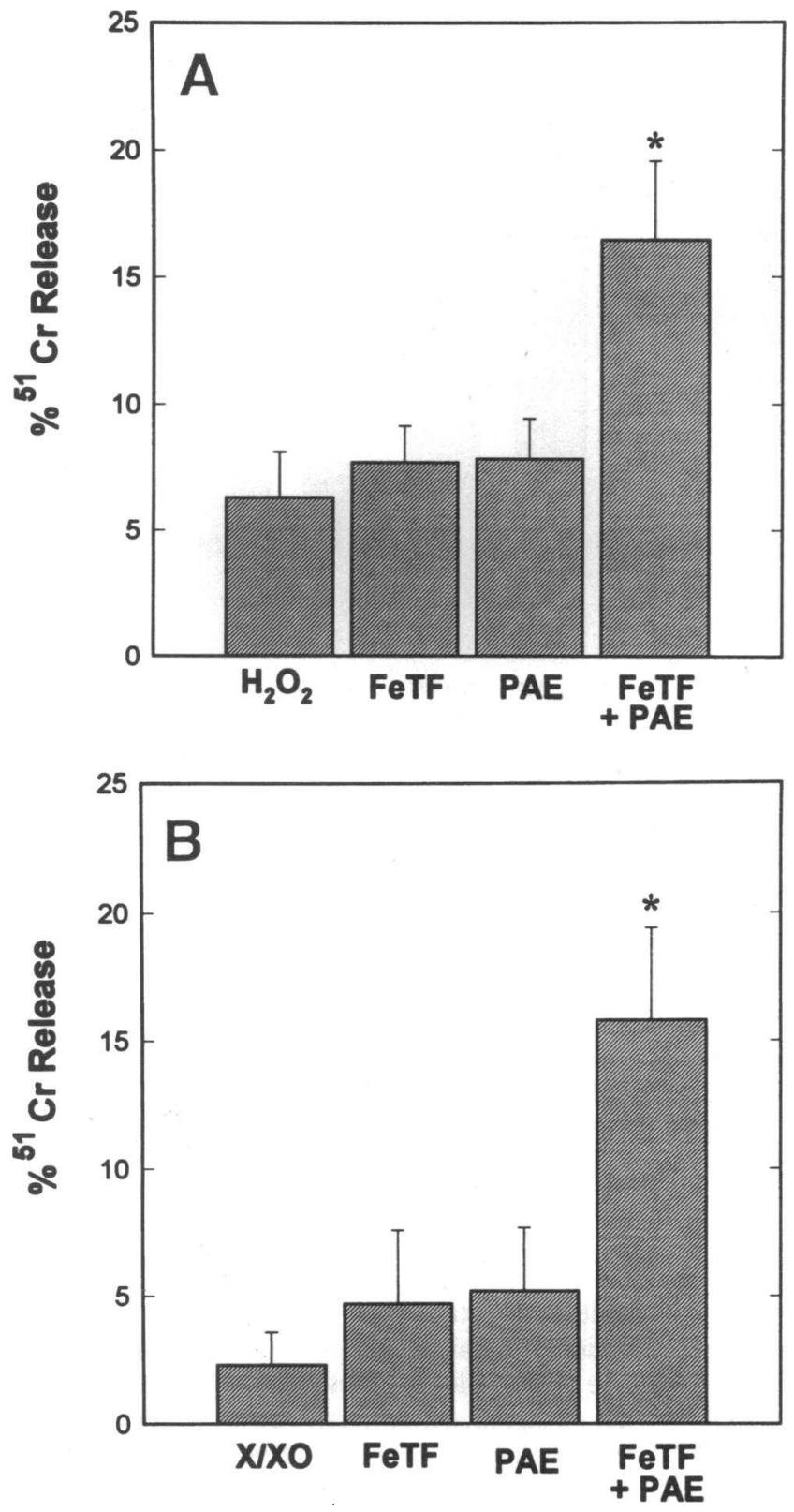

Figure 1. (A) Shown is the mean $(n=15, \pm \mathrm{SEM})$ of specific ${ }^{51} \mathrm{Cr}$ release obtained after incubating endothelial cells in the presence of $\mathrm{H}_{2} \mathrm{O}_{2}(5-10 \mu \mathrm{M})$ alone and under conditions in which the cells were preincubated for $30 \mathrm{~min}$ in the presence of PAE-cleaved FeTF (differictransferrin), non-protease-treated FeTF, or PAE alone $\left({ }^{*} P<0.01\right.$ versus $\mathrm{H}_{2} \mathrm{O}_{2}$ alone $)$. ( $\left.B\right)$ Shown is the mean $(n=6, \pm \mathrm{SEM})$ of specific ${ }^{51} \mathrm{Cr}$ release obtained after incubating endothelial cells in the presence of xanthine $(100 \mu \mathrm{M}) /$ xanthine oxidase $(0.1 \mathrm{U} / \mathrm{ml})$ alone $(X / X O)$ and under conditions in which the cells were preincubated for $30 \mathrm{~min}$ in the presence of PAE-cleaved FeTF, non-protease-treated FeTF, or PAE

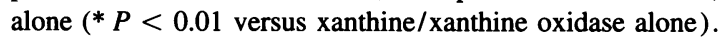

incubated with uncleaved Fe-transferrin or PAE alone followed by $\mathrm{H}_{2} \mathrm{O}_{2}$ addition yielded ${ }^{51} \mathrm{Cr}$ release which was not statistically different from $\mathrm{H}_{2} \mathrm{O}_{2}$ alone (Fig. $1 \mathrm{~A}$ ). Using xanthine/xanthine oxidase as the oxidant source, results were similar to those seen with $\mathrm{H}_{2} \mathrm{O}_{2}$ (Fig. $1 \mathrm{~B}$ ). ${ }^{51} \mathrm{Cr}$ release was $15.8 \%$ of maximum with PAE-cleaved Fe-transferrin as compared with $2.3 \%$ with xanthine/xanthine oxidase alone $(n=6, P<0.01)$. Once

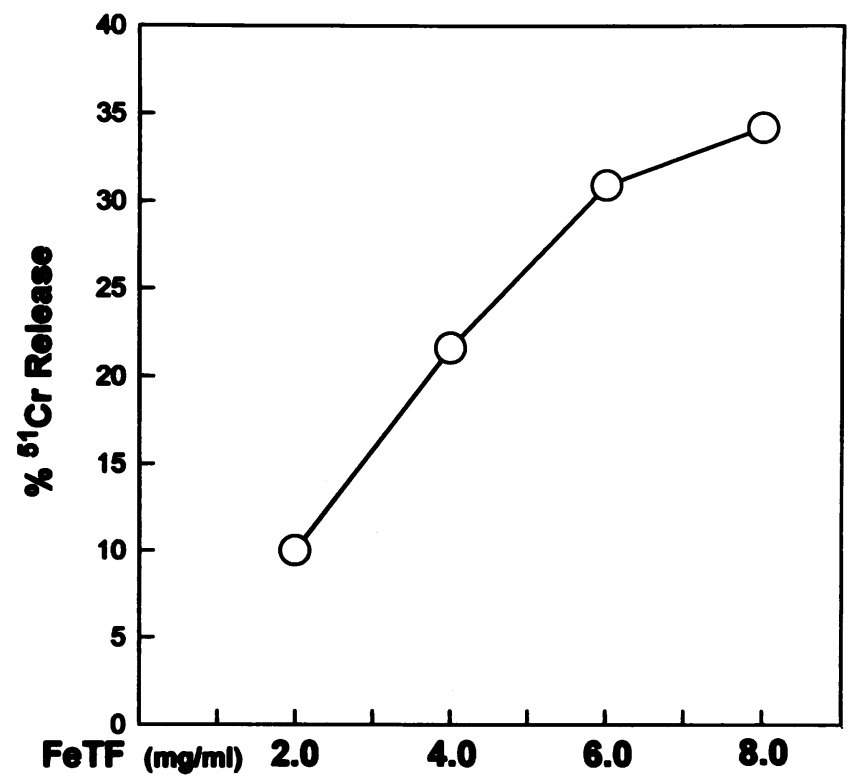

Figure 2. Dose-response curve representative of three separate ${ }^{51} \mathrm{Cr}$ release endothelial cell injury assays resulting from exposure of endothelial cells to $10 \mu \mathrm{M} \mathrm{H}_{2} \mathrm{O}_{2}$ in the presence of increasing concentrations of PAE-cleaved FeTF.

again, control Fe-transferrin and PAE alone did not augment xanthine/xanthine oxidase-associated cell injury (Fig. $1 \mathrm{~B}$ ).

Experiments performed with increasing concentrations of PAE-cleaved Fe-transferrin and Fe-transferrin and PAE controls in the presence of $10 \mu \mathrm{M} \mathrm{H}_{2} \mathrm{O}_{2}$ revealed a dose-dependent increase in ${ }^{51} \mathrm{Cr}$ release with the Fe-transferrin cleavage products with minimal increases in Fe-transferrin and PAE controls (Fig. $2)$. Although the higher concentration of the Fe-transferrin cleavage products yielded the most ${ }^{51} \mathrm{Cr}$ release, the variability between the triplicate samples also increased. In addition, this Fe-transferrin concentration is in excess of that expected under most in vivo conditions, as serum concentrations of Fe-transferrin range from 2 to $4 \mathrm{mg} / \mathrm{ml}(44)$. Therefore, the concentrations of Fe-transferrin and PAE present in all subsequent endothelial cell injury assays were $4 \mathrm{mg} / \mathrm{ml}$ and $3 \mu \mathrm{g} / \mathrm{ml}$, respectively.

As PMNs are present in high concentrations at sites of $P$. aeruginosa infection and other forms of inflammation, PMNs would likely serve as the source of $\mathrm{H}_{2} \mathrm{O}_{2}$ and $\cdot \mathrm{O}_{2}^{-}$in vivo. Thus, experiments were repeated using PMA-stimulated PMNs as the oxidant source in place of $\mathrm{H}_{2} \mathrm{O}_{2}$ and xanthine/xanthine oxidase in the endothelial cell injury assay. The results were similar in that ${ }^{51} \mathrm{Cr}$ release increased from 2.4 to $17 \%$ of maximum in the presence of PAE-cleaved Fe-transferrin $(n=12, P<0.001)$ but not PAE alone (Fig. 3). Non-protease-treated Fe-transferrin also caused a statistically significant increase in injury above PMNs alone. However, the magnitude of the increase was still significantly less than PAE-cleaved Fe-transferrin (Fig. 3).

To further assess the mechanism whereby PAE-cleaved Fetransferrin augments oxidant-mediated endothelial cell injury, a series of experiments was done to determine which components were necessary in mediating the increase in endothelial cell injury observed with PAE-cleaved Fe-transferrin. Studies performed with PAE-cleaved apotransferrin yielded no signifi- 


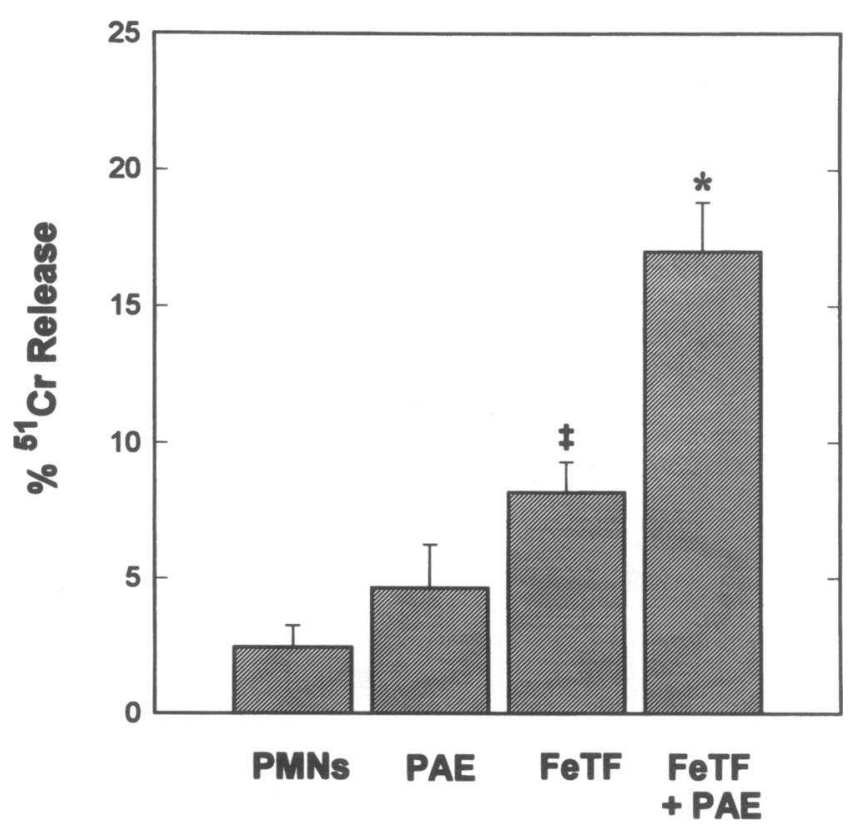

Figure 3. Shown is the mean $(n=12, \pm \mathrm{SEM})$ of specific ${ }^{51} \mathrm{Cr}$ release obtained after incubating endothelial cells in the presence of PMAstimulated PMNs $\left(2.5 \times 10^{3-4}\right.$ cells/well $)$ alone and under conditions in which the endothelial cells were preincubated for $30 \mathrm{~min}$ in the presence of PAE-cleaved FeTF ( $P<0.001$ versus PMNs alone), non-protease-treated FeTF ( ${ }^{\ddagger} P<0.01$ versus PMNs alone), or PAE alone.

cant increase in endothelial cell injury regardless of the oxidant used (Fig. 4), establishing the role of iron in mediating injury. The iron responsible for injury appears to be that associated with the cleaved Fe-transferrin and not simply iron released from the protein during cleavage, as the addition of free iron in the form of $\mathrm{FeCl}_{3}(100 \mu \mathrm{M})$ did not result in a significant increase in injury when added to each oxidant system (Fig. 4). Fe-transferrin treated with heat-inactivated PAE $\left(100^{\circ} \mathrm{C}\right.$ for 10 min) also failed to augment oxidant-mediated endothelial cell injury (Fig. 4), demonstrating the need for the Fe-transferrin to be treated with an active enzyme in order for endothelial cell injury to occur. To determine whether the oxidant source was necessary to augment endothelial cell injury with the PAEcleaved Fe-transferrin, studies were performed assessing ${ }^{51} \mathrm{Cr}$ release with and without the presence of $\mathrm{H}_{2} \mathrm{O}_{2}$, xanthine/xanthine oxidase, or PMA-stimulated PMNs. Regardless of the oxidant used, the preincubation of endothelial cells with PAEcleaved Fe-transferrin caused significant injury only when the oxidant was added later. These findings suggest that the enhancement in endothelial cell injury is iron dependent, oxidant mediated, and requires exposure of Fe-transferrin to an active enzyme to observe a maximum effect.

Is the endothelial cell injury mediated by $\cdot \mathrm{OH}$ ? We have previously demonstrated the formation of $\cdot \mathrm{OH}$ with PAEcleaved Fe-transferrin when added to a hypoxanthine/xanthine oxidase or PMA-stimulated $\mathrm{PMN} \cdot \mathrm{O}_{2}^{-} / \mathrm{H}_{2} \mathrm{O}_{2}$ generating system (31). Postulating that the iron-dependent augmentation in endothelial cell injury results from $\cdot \mathrm{OH}$ formation, studies assessing the role of $\cdot \mathrm{OH}$ scavengers and other antioxidant compounds in inhibiting cell injury were performed. Regardless of whether $\mathrm{H}_{2} \mathrm{O}_{2}$ or PMA-stimulated PMNs were used as the oxidant

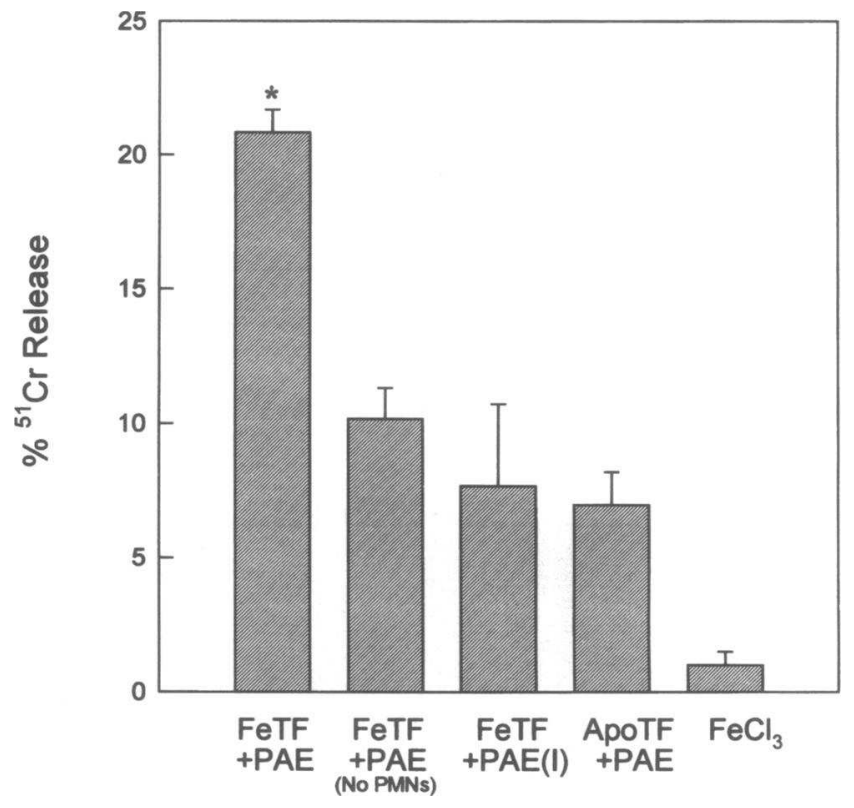

Figure 4. Shown are mean specific ${ }^{51} \mathrm{Cr}$ release data $( \pm \mathrm{SEM})$ obtained after incubating endothelial cells in the presence of PMA-stimulated PMNs $\left(2.5 \times 10^{3-4}\right)$ under conditions in which the cells were preincubated for $30 \mathrm{~min}$ in the presence of PAE-cleaved FeTF (left) or four control groups (right). Mean ${ }^{51} \mathrm{Cr}$ release for PMA-stimulated PMNs alone was $2.5 \%(n=32,0.42)$ for all groups. PAE-cleaved FeTF versus PAE-cleaved FeTF in the absence of PMA-stimulated PMNs $(n=11)$. PAE-cleaved FeTF versus FeTF incubated with heat-inactivated PAE $(n=6)$. PAE-cleaved FeTF versus PAE-cleaved apo-TF $(n=8)$. PAE-cleaved FeTF versus a similar concentration of $\mathrm{FeCl}_{3}(n=7)$. ${ }^{*} P<0.01$ versus control group and $\mathrm{PMNs}$ alone. Although not shown, results were similar using xanthine/xanthine oxidase $(n=5-7)$ or $\mathrm{H}_{2} \mathrm{O}_{2}$ $(n=6-7)$ as the oxidant source.

source, the addition of catalase and DMTU to test wells containing PAE-cleaved Fe-transferrin resulted in a statistically significant decrease in ${ }^{51} \mathrm{Cr}$ release (Table I). The addition of SOD and DMSO had no significant protective effects (Table I). The site of $\cdot \mathrm{OH}$ formation is a critical element in determining the magnitude of resulting cell injury. To further explore the location of the iron-dependent oxidant leading to cytotoxicity, the capacity of two additional $\cdot \mathrm{OH}$ scavengers with differing hydrophobicity to inhibit cell injury was measured. Spin traps are nitrones (or nitroso compounds) which readily react with oxidant species (45). The hydrophobic spin trap, PBN, demonstrated the most protection (58.2\%) of all the inhibitors studied, whereas the hydrophilic spin trap, 4-POBN, showed no significant effect (Table I). These results are consistent with the possibility that formation of reactive oxygen intermediates, such as - $\mathrm{OH}$ at hydrophobic sites, contributes to endothelial cell injury resulting from the presence of PAE-cleaved Fe-transferrin.

Given the above data, spin trapping studies were performed to provide additional evidence supporting the role of $\cdot \mathrm{OH}$ in mediating endothelial cell injury. The highly sensitive and specific 4-POBN/ethanol system was used for detecting $\cdot \mathrm{OH}$. Exposure of porcine pulmonary artery endothelial cells cultured on microcarrier beads to PAE-cleaved Fe-transferrin in combination with PMA-stimulated PMNs resulted in significantly more $\cdot \mathrm{OH}$ formation than that seen with endothelial cells exposed to PMA-stimulated PMNs alone or in association with 
Table I. Effects of Antioxidant Enzymes and $\cdot$ OH Scavengers on Oxidant-mediated Endothelial Cell Injury

\begin{tabular}{|c|c|c|c|c|c|c|}
\hline & \multicolumn{6}{|c|}{ Percent decrease in ${ }^{51} \mathrm{Cr}$ release } \\
\hline & \multicolumn{2}{|c|}{ FeTF + PAE } & \multicolumn{2}{|c|}{ FeTF + PPE } & \multicolumn{2}{|c|}{ FeTF + trypsin } \\
\hline & $\mathrm{H}_{2} \mathrm{O}_{2}$ & PMNs & $\mathrm{H}_{2} \mathrm{O}_{2}$ & PMNs & $\mathrm{H}_{2} \mathrm{O}_{2}$ & PMNs \\
\hline PBN & $50.7(2.4)^{*}$ & $58.2(1.3)^{*}$ & $59.3(1.8)^{*}$ & ND & $39.2(3.2)^{*}$ & $51.1(3.7)^{*}$ \\
\hline Catalase & $44.3(2.4)^{*}$ & $34.1(2.7)^{*}$ & $18.3(2.5)^{*}$ & $13.8(1.6)^{*}$ & $42.4(2.0)^{*}$ & $35.7(3.0)^{*}$ \\
\hline DMTU & $27.8(3.5)^{*}$ & $38.7(4.3)^{*}$ & $31.7(2.1)^{*}$ & $18.2(1.8)^{*}$ & $7.5(6.4)$ & $10.9(2.5)$ \\
\hline SOD & $5.6(3.2)$ & $21.2(3.5)$ & $3.6(3.8)$ & $6.4(2.7)$ & $2.2(7.3)$ & $11.0(4.9)$ \\
\hline 4-POBN & $11.9(5.1)$ & $15.4(2.3)$ & $8.6(3.8)$ & $14.6(1.5)$ & $7.5(4.4)$ & $6.9(2.8)$ \\
\hline DMSO & $-22.7(3.4)^{*}$ & $-47.2(3.7)^{*}$ & $-3.6(3.9)$ & $1.4(1.9)$ & $-1.5(6.4)$ & $-2.5(3.1)$ \\
\hline
\end{tabular}

These data demonstrate the mean ( \pm SEM) percent decrease in ${ }^{51} \mathrm{Cr}$ release for endothelial cells treated with FeTF cleaved with PAE, PPE, or trypsin, and $\mathrm{H}_{2} \mathrm{O}_{2}$ or PMA-stimulated neutrophils (PMNs) in the presence of various antioxidant enzymes and $\cdot \mathrm{OH}$ scavengers. ${ }^{*} P<0.05$ versus protease-cleaved FeTF and the oxidant alone, not done (ND).

the presence of noncleaved Fe-transferrin (Fig. 5). The substitution of PAE-cleaved apotransferrin for cleaved Fe-transferrin in the endothelial cell and PMA-stimulated PMN system eliminated spin adduct generation, demonstrating the necessity for iron in the system and providing further evidence for involvement of the Haber-Weiss reaction. When $\mathrm{H}_{2} \mathrm{O}_{2}$ was used in place of PMA-stimulated PMNs, the results were similar (data not shown).

The presence of $\mathrm{O}_{2}^{-}$generated by the xanthine/xanthine oxidase reaction or by PMA-stimulated PMNs systems provides a means of reducing the $\mathrm{Fe}^{+3}$ bound to transferrin to $\mathrm{Fe}^{+2}$ which would be required for the formation of $\cdot \mathrm{OH}$ via the HaberWeiss reaction in our cell injury and spin trapping systems. In contrast, with the use of $\mathrm{H}_{2} \mathrm{O}_{2}$ as an oxidant source, there is no source of $\cdot \mathrm{O}_{2}^{-}$to reduce the $\mathrm{Fe}^{+3}$ used with transferrin to form -OH in the classic Haber-Weiss reaction. Nevertheless, as discussed above, cleaved $\mathrm{Fe}$-transferrin augmented $\mathrm{H}_{2} \mathrm{O}_{2}$-mediated endothelial cell injury and yielded spin trap detectable $\cdot \mathrm{OH}$. One possible explanation for these observations was that the endothelial cell was providing the reducing equivalents required for the formation of $\mathrm{Fe}^{+2}$ which then interacted with $\mathrm{H}_{2} \mathrm{O}_{2}$ to generate $\cdot \mathrm{OH}$. However, spin trapping studies in which $\mathrm{H}_{2} \mathrm{O}_{2}$ was mixed with PAE-cleaved transferrin also in the absence of endothelial cells also demonstrated significant $\cdot \mathrm{OH}$ formation. This was not observed with noncleaved Fe-transferrin or $\mathrm{H}_{2} \mathrm{O}_{2}$ alone (Fig. 6). This suggests that the endothelial cell itself does not need to serve as a reducing. source in order for $\cdot \mathrm{OH}$ or an oxidant with properties analogous to $\cdot \mathrm{OH}$ to be generated during the reaction of $\mathrm{H}_{2} \mathrm{O}_{2}$ and PAE-cleaved Fe-transferrin.

The ability of Fe-transferrin cleaved with other proteases to augment oxidant-mediated endothelial cell injury. Sites of $P$. aeruginosa infection and other types of inflammation are characterized by increased proteolytic activity mediated by proteases other than PAE. These proteases are also known to cleave Fe-transferrin $(3,46-50)$. In an earlier study, we found that although trypsin and human PMN elastase cleave Fe-transferrin, these cleavage products lacked the ability to catalyze $\cdot \mathrm{OH}$ generation as assessed using the formation of TBA-reactive 2-deoxyribose oxidation products as the $\cdot \mathrm{OH}$ detection system (31). As a means of assessing the uniqueness of PAE-cleaved Fetransferrin, we examined whether oxidant-mediated endothelial cell injury was augmented by Fe-transferrin cleaved with trypsin or PPE, an enzyme similar in function to human PMN elastase
(51). The cost of human PMN elastase was prohibitive for these studies given the quantity necessary to generate the $\mathrm{Fe}$ transferrin cleavage products required. SDS-PAGE confirmed

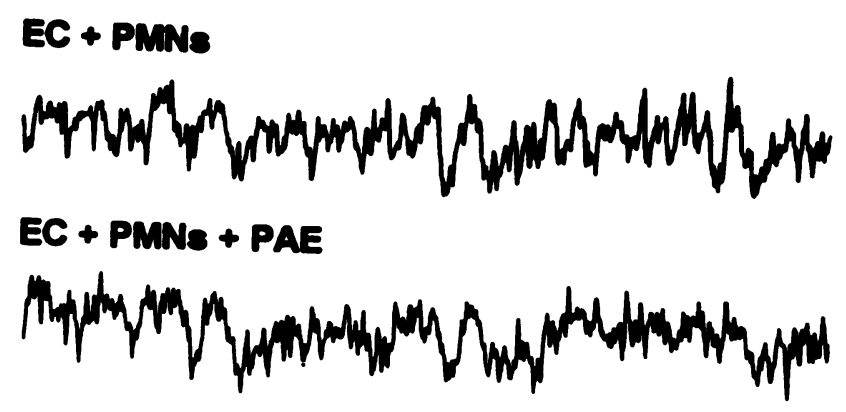

$E C+$ PMNs + FeTF

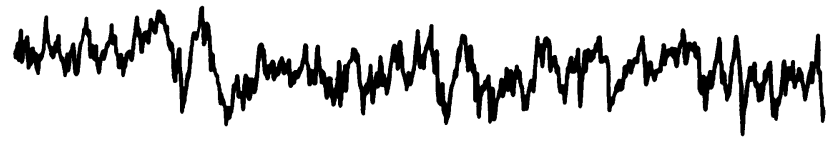

EC + PMNS + FeTF / PAE
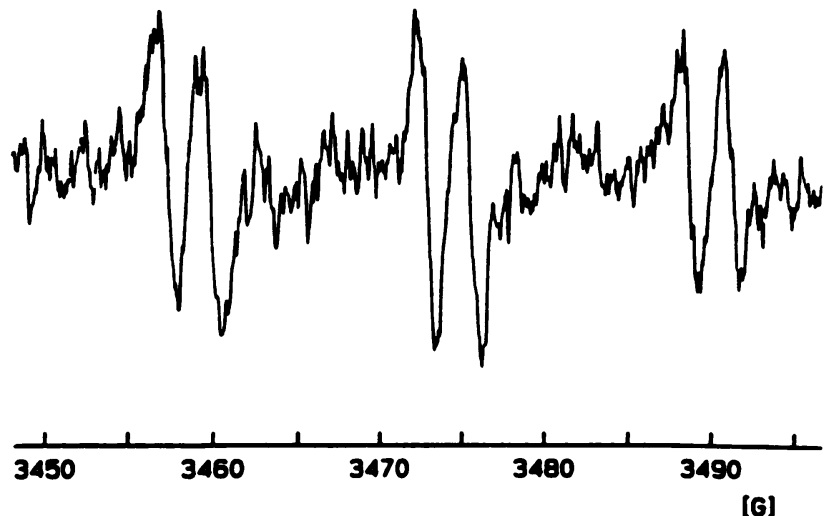

[G]

Figure 5. EPR spectra representative of three separate experiments obtained after the addition of PMA-stimulated PMNs to 4-POBN, ethanol, endothelial cells, and DPTA as well as the same reaction mixture supplemented with FeTF ( $50 \mu \mathrm{M}$ Fe, $25 \mu \mathrm{M}$ TF), PAE ( $20 \mu \mathrm{g} / \mathrm{ml}$ ), or the same concentration of FeTF previously cleaved with that amount of PAE. The species detected is that of the 4-POBN/. $\mathrm{CHOHCH}_{3}$ spin adduct, indicating $\cdot \mathrm{OH}$ production. 
$\mathrm{H}_{2} \mathrm{O}_{2}$

\section{$\mathrm{H}_{2} \mathrm{O}_{2}+\mathrm{FeTF}$}
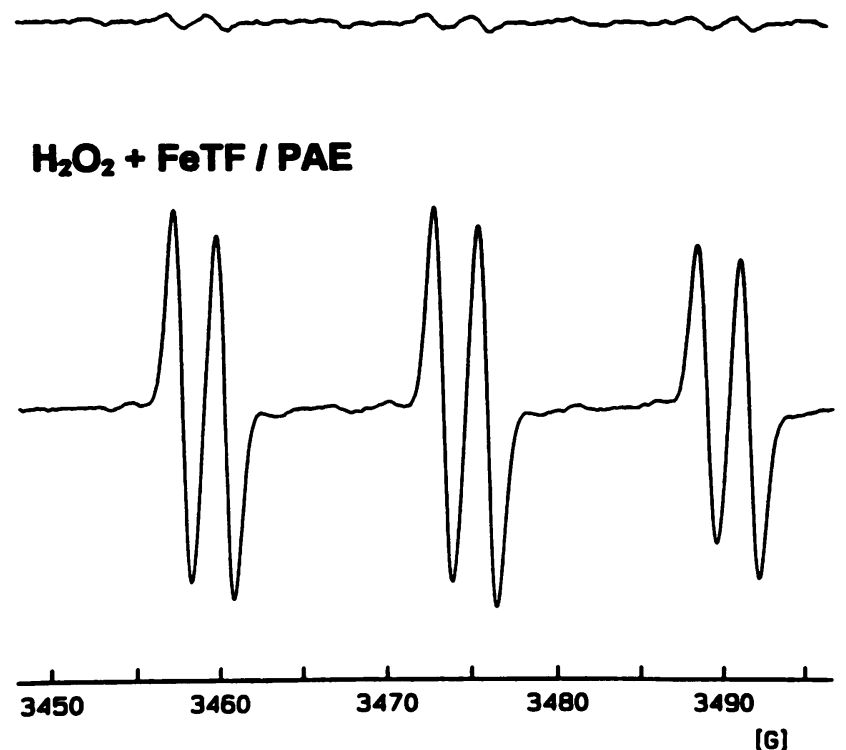

[G]

Figure 6. EPR spectra representative of three separate experiments obtained after the addition of $\mathrm{H}_{2} \mathrm{O}_{2}(10 \mu \mathrm{M})$ to 4-POBN, ethanol, and DTPA as well as the same reaction supplemented with FeTF ( $50 \mu \mathrm{M}$ Fe, $25 \mu \mathrm{M}$ TF) or FeTF previously cleaved with PAE. The species detected is that of the 4-POBN/. $\mathrm{CHOHCH}_{3}$ spin adduct, indicating $\cdot \mathrm{OH}$ formation.

the ability of both PPE and trypsin to cleave Fe-transferrin as illustrated by the presence of two prominent and several other lower molecular weight bands as compared with the Fe-transferrin standard (not shown). Although the cleavage pattern was different for trypsin, PPE, and PAE, the relative magnitudes of cleavage were similar, suggesting similar protease activity toward Fe-transferrin under these conditions. Using the same ${ }^{51} \mathrm{Cr}$ release endothelial cell injury assay employed in the PAE studies, trypsin- or PPE-cleaved Fe-transferrin significantly increased endothelial cell injury resulting from exposure to $\mathrm{H}_{2} \mathrm{O}_{2}$ or PMA-stimulated PMNs (Fig. 7). Parallel experiments performed with trypsin and PPE in the absence of Fe-transferrin demonstrated no significant increase in ${ }^{51} \mathrm{Cr}$ release. The augmentation of endothelial cell injury with trypsin- and PPEcleaved Fe-transferrin was generally less than that observed with PAE-cleaved Fe-transferrin (Fig. 7). However, this difference did not reach statistical significance.

Regardless of whether PMA-stimulated PMNs or $\mathrm{H}_{2} \mathrm{O}_{2}$ was used as the oxidant source, neither trypsin-nor PPE-cleaved apotransferrin produced a significant increase in ${ }^{51} \mathrm{Cr}$ release, establishing the necessity of iron in association with the cleaved transferrin in mediating endothelial cell injury. Furthermore, Fe-transferrin treated with heat-inactivated trypsin or PPE $\left(100^{\circ} \mathrm{C}\right.$ for $10 \mathrm{~min}$ ) also showed no augmentation in endothelial cell injury.

Is the augmentation in endothelial cell injury by trypsin-

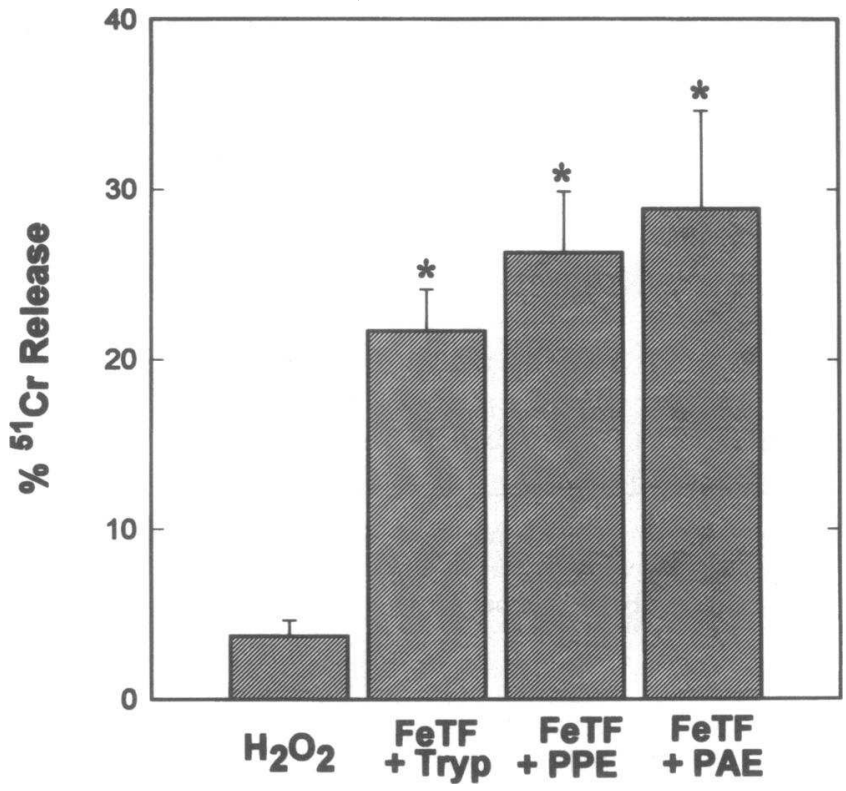

Figure 7. Shown is the mean $\left(n=15, \pm\right.$ SEM) of specific ${ }^{51} \mathrm{Cr}$ release obtained after incubating endothelial cells in the presence of $\mathrm{H}_{2} \mathrm{O}_{2}$ (5$10 \mu \mathrm{M}$ ) alone or after preincubating for $30 \mathrm{~min}$ in the presence of FeTF cleaved with PAE, PPE, or trypsin $\left(* P<0.001\right.$ versus $\mathrm{H}_{2} \mathrm{O}_{2}$ alone $)$.

and PPE-cleaved Fe-transferrin mediated by $\bullet \mathrm{OH}$ ? Given the similar ability of PPE- and trypsin-cleaved Fe-transferrin relative to PAE-cleaved Fe-transferrin to augment oxidant-mediated damage to endothelial cells, we examined whether $\cdot \mathrm{OH}$ formation is also linked to the effects of trypsin and PPE-cleaved Fetransferrin on endothelial cells.

The abilities of antioxidant compounds and $\cdot \mathrm{OH}$ scavengers to inhibit cytotoxicity were assessed using the ${ }^{51} \mathrm{Cr}$ release cell injury assay. Similar to data obtained with PAE-cleaved Fetransferrin, DMTU, catalase, and PBN provided significant protection from injury resulting from the presence of PPE-cleaved Fe-transferrin and $\mathrm{H}_{2} \mathrm{O}_{2}$ (Table $\mathrm{I}$ ). SOD, 4-POBN, and DMSO had no significant protective effects (Table I). Experiments substituting PMA-stimulated PMNs in place of $\mathrm{H}_{2} \mathrm{O}_{2}$ as the oxidant source yielded similar results. Inhibitor studies performed with trypsin-cleaved Fe-transferrin in the presence of PMA-stimulated PMNs or $\mathrm{H}_{2} \mathrm{O}_{2}$ also revealed a significant protective effect from catalase and PBN, whereas SOD, DMSO, and 4-POBN offered no protection. Unique to trypsin-cleaved Fe-transferrin, DMTU had no protective effect. As with PAEcleaved Fe-transferrin, these results suggest that reactive oxygen intermediates are likely involved in mediating cytotoxicity. In addition, the location of the generation of these reactive intermediates and site of action of the specific inhibitor appear to be crucial to the process.

To more directly assess the role of $\cdot \mathrm{OH}$ formation in mediating this process, spin trapping studies were performed. Using the 4-POBN/ethanol system, $\cdot \mathrm{OH}$ was detected with trypsinand PPE-cleaved Fe-transferrin in the presence of $\mathrm{H}_{2} \mathrm{O}_{2}$ and PMA-stimulated PMNs (Fig. 8). consistent with the above spin trapping studies, $\cdot \mathrm{OH}$ was detected regardless of the presence or absence of endothelial cells (data not shown). The quantity of $\cdot \mathrm{OH}$ generated, however, was less than that seen with PAEcleaved Fe-transferrin (Fig. 8). This qualitatively correlated 

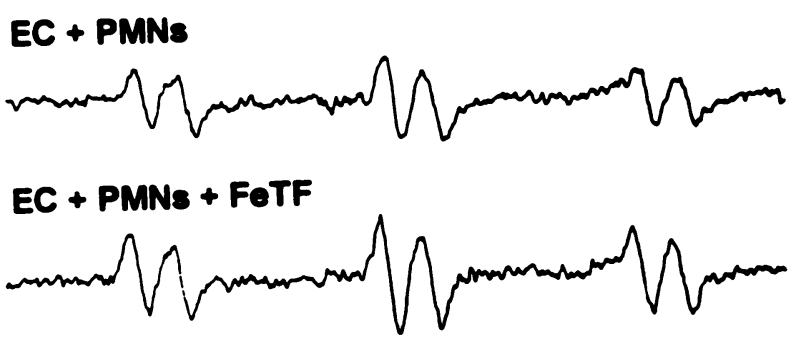

\section{$E C+$ PMNs + FeTF / Trypsin}

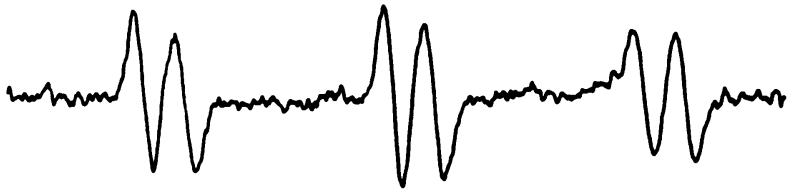

$$
\text { EC + PMNS + FETF I PPE }
$$

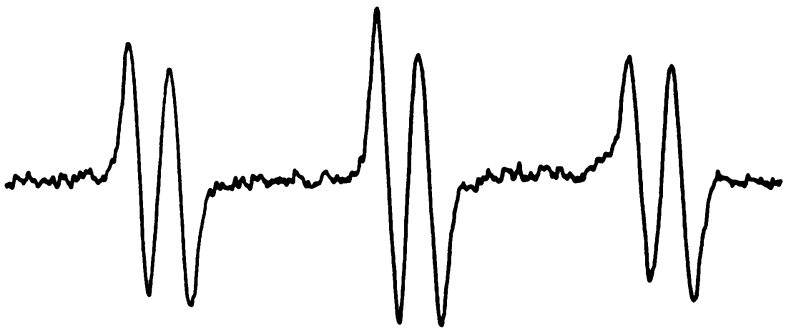

$$
E C+\text { PMNs + FeTF I PAE }
$$
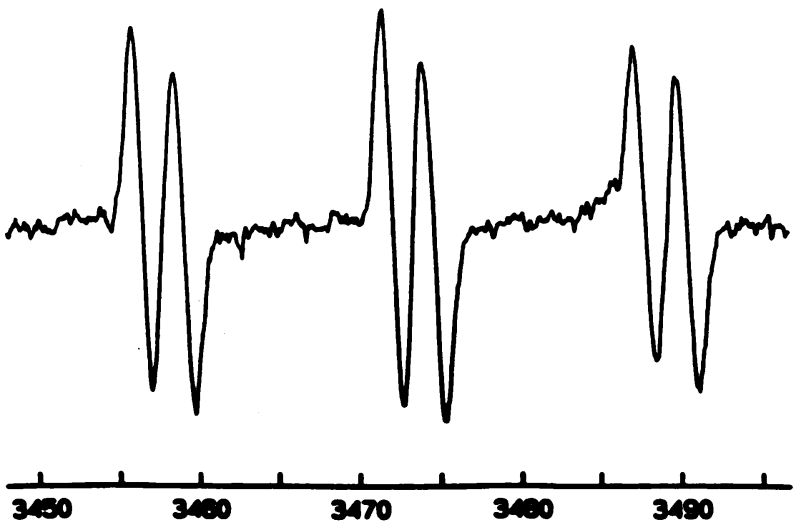

[e]

Figure 8. EPR spectra representative of three separate experiments obtained after the addition of PMA-stimulated PMNs to 4-POBN, ethanol, endothelial cells, and DTPA as well as the same reaction mixture supplemented with FeTF ( $50 \mu \mathrm{M}$ Fe, $25 \mu \mathrm{M}$ TF) or FeTF previously cleaved with trypsin, PPE, or PAE. The species detected is that of the 4-POBN/ $\cdot \mathrm{CHOHCH}_{3}$ spin adduct, indicating $\cdot \mathrm{OH}$ production.

with the amount of cell injury observed for all three protease cleavage products in the ${ }^{51} \mathrm{Cr}$ release assay (Fig. 7).

Using a method for detecting the formation of TBA-reactive 2-deoxyribose oxidation products, we reported previously that -OH formation could be catalyzed by PAE-cleaved Fe-transferrin, but not with Fe-transferrin cleaved with trypsin and human PMN elastase (31). This assay, however, is somewhat less sensitive and specific than spin trapping for detecting $\cdot \mathrm{OH}$. As the above cell injury and spin trapping studies appeared to demonstrate a discrepancy with our previous results, $\cdot \mathrm{OH}$ formation was again assessed using the deoxyribose assay. By
Table II. Confirmation of $\cdot \mathrm{OH}$ Formation by the Generation of TBA-reactive 2-Deoxyribose Oxidation Products

\begin{tabular}{ll}
\hline & Absorbance $(532 \mathrm{~nm})$ \\
\hline FeTF + PAE & $0.0425( \pm 0.0087)^{*}$ \\
FeTF + PPE & $0.0406( \pm 0.0103)^{*}$ \\
FeTF + trypsin & $0.0227( \pm 0.0076)^{\ddagger}$ \\
\hline
\end{tabular}

Formation of TBA-reactive 2-deoxyribose oxidation products $(532 \mathrm{~nm}$ absorbance) reflecting formation of $\cdot \mathrm{OH}$ by reaction mixtures composed of hypoxanthine, xanthine oxidase, and FeTF alone or FeTF previously cleaved with PAE, PPE, or trypsin. The absorbance expressed represents the mean $(n=10, \pm S E M)$ obtained with the respective protease-cleaved FeTF less the absorbance obtained with a paired FeTF control. ${ }^{*} P$ $<0.001,{ }^{\ddagger} P<0.05$ versus the FeTF control.

generating more replicates than performed in the earlier study (31), we were able to show a small but statistically significant increase in detectable $\cdot \mathrm{OH}$ formation with trypsin-cleaved $\mathrm{Fe}$ transferrin relative to the Fe-transferrin control (Table II). PPEcleaved Fe-transferrin also demonstrated a significant increase in $\cdot \mathrm{OH}$ formation compared with the Fe-transferrin control ( Table II).

\section{Discussion}

$P$. aeruginosa infections are characterized by marked inflammation and subsequent tissue injury which is thought to contribute to the high morbidity and mortality seen in patients with pneumonia and cystic fibrosis $(1,34,52,53)$. Bacteria- and PMN-derived proteases and to a lesser extent PMN oxidant formation have both been implicated in mediating this tissue injury $(1-7,54)$, but the primary mechanism is largely unknown. Previous data from our laboratory have suggested that -OH formation may be involved in protease-mediated injury as PAE, a $P$. aeruginosa-derived protease, can cleave Fe-transferrin into smaller iron chelates which in the presence of an oxidant source are able to catalyze $\cdot \mathrm{OH}$ formation (31). Based on these findings and that acute, and to a lesser extent chronic, forms of $P$. aeruginosa infection of the lung have been shown to result in pulmonary microvasculature damage $(33-36)$, the ability of the PAE and other protease-cleaved Fe-transferrin to augment oxidant-mediated endothelial cell injury via $\cdot \mathrm{OH}$ formation was examined.

Using a ${ }^{51} \mathrm{Cr}$ release assay, we demonstrated a significant augmentation in oxidant-mediated porcine pulmonary artery endothelial cell injury with PAE-, trypsin-, and PPE-cleaved Fetransferrin, regardless of the oxidant source employed, including PMA-stimulated PMNs. Fe-transferrin alone, the proteases alone, and $\mathrm{Fe}$-transferrin treated with heat-inactivated protease all failed to demonstrate any augmentation in cell injury, establishing the need for an active protease in combination with $\mathrm{Fe}$ transferrin in mediating injury. This process also appears to be dependent on iron associated with Fe-transferrin, as no augmentation in cell injury was seen with protease-cleaved apotransferrin or $\mathrm{FeCl}_{3}$. Control studies performed with the iron chelates in the absence of an oxidant source failed to induce cell injury. This is consistent with the hypothesis that the iron is acting as a catalyst for the Haber-Weiss reaction rather than through the direct induction of membrane peroxidation. 
Further evidence that $\cdot \mathrm{OH}$ formation contributed to the observed enhancement in endothelial cell injury was provided by studying the effects of antioxidant compounds and $\cdot \mathrm{OH}$ scavengers on inhibiting endothelial cell injury. Not unexpectedly, catalase, an enzyme which removes $\mathrm{H}_{2} \mathrm{O}_{2}$ from the system, significantly protected the endothelial cells from injury regardless of which protease was used to cleave Fe-transferrin or which oxidant system was employed. Likewise, DMTU, a $\mathrm{H}_{2} \mathrm{O}_{2}$ and $\cdot \mathrm{OH}$ scavenger, protected from oxidant-mediated injury with PAE- and PPE-cleaved Fe-transferrin. The fact that it had only a small protective effect with trypsin-cleaved $\mathrm{Fe}$-transferrin that was not statistically significant remains unexplained. SOD, an enzyme which catalyzes the dismutation of $\cdot \mathrm{O}_{2}^{-}$, did not exhibit protection from oxidant-mediated endothelial cell injury when added with any of the transferrin cleavage products. SOD may be unable to reach the site of where $\cdot \mathrm{O}_{2}^{-}$interacts with the iron chelate. Alternatively, $\cdot \mathrm{O}_{2}^{-}$may not be a critical component in $\cdot \mathrm{OH}$ generation. This is discussed in greater detail later. Interestingly, DMSO, another $\cdot \mathrm{OH}$ scavenger, also demonstrated no protection from injury. This combination actually augmented endothelial cell injury in the case of PAE-cleaved Fe-transferrin. A potential explanation may be the formation of a more stable methyl radical resulting from the reaction of $\cdot \mathrm{OH}$ with the methyl groups of DMSO. This radical in turn could be cytotoxic, thereby accounting for the absence of a protective effect or the enhancement of endothelial cell injury seen with PAE-cleaved Fe-transferrin.

Detection of ${ }^{51} \mathrm{Cr}$ release provides evidence only of cell injury, but does not allow specific insight into determining the site of that injury. The two spin traps, PBN and 4-POBN, provided some insight into this mechanism of enhancement of oxidant-mediated endothelial cell injury by the various Fe-transferrin cleavage products. With PBN, a hydrophobic compound, a $39-59 \%$ reduction in injury was observed, the most of any of the inhibitors studied. In contrast, 4-POBN, a hydrophilic compound, had no protective effect. Since both compounds have similar reactivity toward $\cdot \mathrm{OH}(45,55)$, these findings suggest that the site of $\cdot \mathrm{OH}$ formation may be crucial in its role of mediating injury and imply that a hydrophobic locale such as the plasma membrane may be the critical site of injury. Additionally, PBN could be acting via a mechanism independent of oxidant scavenging such as in modulation in physical preparations of the cell membrane. Further studies are required to define the cellular targets whose damage leads to the release of ${ }^{51} \mathrm{Cr}$, e.g., oxidation of intracellular proteins or membrane peroxidation.

Spin trapping studies provided more direct evidence for $\cdot \mathrm{OH}$ formation in mediating endothelial cell injury. Using the 4POBN/ethanol system when endothelial cells were exposed to either $\mathrm{H}_{2} \mathrm{O}_{2}$ or PMA-stimulated PMNs as the oxidant source, significantly more $\cdot \mathrm{OH}$ was detected with PAE-, PPE-, or trypsin-cleaved Fe-transferrin than with Fe-transferrin or the oxidant source alone. The quantity of $\cdot \mathrm{OH}$ generated with trypsin- and PPE-cleaved Fe-transferrin was generally less than that observed with PAE-cleaved Fe-transferrin. However, this difference did not reach statistical significance. It is worth noting that the relative activity of each of these proteases under the microenvironmental conditions at sites of $P$. aeruginosa infection in vivo could be quite different than those relative activities we observed in our specific experimental system. Thus, the relative potency of the three proteases we observed with regard to transferrin cleavage may not hold in vivo.
Both $\cdot \mathrm{O}_{2}^{-}$and $\mathrm{H}_{2} \mathrm{O}_{2}$ are products of the xanthine/xanthine oxidase reaction and are released after PMA stimulation of PMNs. Superoxide in these systems reduces $\mathrm{Fe}^{+3}$ to the catalytic form, $\mathrm{Fe}^{+2}$, which is now capable of participating in the HaberWeiss reaction to generate $\cdot \mathrm{OH}$. The studies performed with $\mathrm{H}_{2} \mathrm{O}_{2}$ as the oxidant source lack a source of $\mathrm{O}_{2}^{-}$as a means of reducing $\mathrm{Fe}^{+3}$ to $\mathrm{Fe}^{+2}$, however, enhanced cell injury and detectable $\cdot \mathrm{OH}$ was observed. The endothelial cell itself does not serve as the reducing source via its endogenous production of $\cdot \mathrm{O}_{2}^{-}$or via another cell-associated reductase system (56), as spin trapping studies performed in which $\mathrm{H}_{2} \mathrm{O}_{2}$ and proteasecleaved Fe-transferrin were mixed in the absence of endothelial cells yielded comparable quantities of $\cdot \mathrm{OH}$. In these $\mathrm{H}_{2} \mathrm{O}_{2}$ studies, the species generated is either $\cdot \mathrm{OH}$ or a $\cdot \mathrm{OH}$-like compound which results from the interaction of $\mathrm{H}_{2} \mathrm{O}_{2}$ and $\mathrm{Fe}^{+3}$ and which is able to cause cell injury in a fashion analogous to $\cdot \mathrm{OH}$. Ferryl species exhibit many of the properties of $\cdot \mathrm{OH}$ and could possibly be generated under such conditions.

The results of our studies are consistent with the hypothesis that protease-cleaved Fe-transferrin enhances oxidant-mediated pulmonary artery endothelial cell injury through the generation of new iron chelates capable of acting as $\cdot \mathrm{OH}$ catalysts. A crucial issue in in vitro studies such as the one reported here is the applicability of these findings to in vivo conditions. Due to obvious technical limitations, no data exist as to the concentration of proteases, transferrin, and transferrin cleavage products present at or near the pulmonary microvascular surface during either acute or chronic forms of $P$. aeruginosa lung infection. However, the concentrations of proteases and Fe-transferrin used in this study approximated those reported to be found in vivo at other nearby sites. In the case of transferrin this includes serum (44) and BAL fluid (57). It should be recognized though that wide variations have been reported in the concentration of enzymatically active PAE present at sites of infection with this organism $(3,46,57-60)$. Reports of PAE activity in airway fluids from $P$. aeruginosa-infected cystic fibrosis patients have varied from nearly $200 \mu \mathrm{g} / \mathrm{ml}$ to none. Unfortunately, none of these studies address the PAE concentrations present near cell surfaces to which $P$. aeruginosa are attached, where levels of the enzyme could be very high. There are no solid data on levels of PAE present at sites of human $P$. aeruginosa infection in conditions other than cystic fibrosis. PPE was used as a HNE analogue in the present study as it has been shown to have similar enzymatic properties and is more economical (51). Limited data are available measuring in vivo concentrations of $\mathrm{HNE}$ $(46,47,61)$. One study found the HNE concentrations in sputum from cystic fibrosis patients to be a mean of $55 \mu \mathrm{g} / \mathrm{ml}$ (range 16-87 $\mu \mathrm{g} / \mathrm{ml}$ ) (46) with other reports finding higher levels (61). Of note, sputum from patients with more advanced disease exhibited increased elastolytic activity (46). Given the approximate 100 -fold dilution BAL specimens are felt to represent (62), HNE concentrations found in vivo are in the range of PPE concentrations used in this study. It is known that trypsin is released from damaged cells $(63,64)$, but no data are available regarding in vivo trypsin concentrations at sites of pulmonary inflammation and injury, thus we can only speculate that the concentration used in this study is of physiologic importance.

The goal of this study was to assess the effects of the protease-cleaved Fe-transferrin on oxidant-mediated injury of the pulmonary microvasculature. Thus, these findings cannot be 
extrapolated to events occurring at the respiratory epithelium, which is the subject of future investigations. The in vitro experimental model used for these studies also has limitations when interpreting these results in the context of the in vivo microvasculature. Our system contained none of the protease inhibitors, antioxidants, or iron-binding proteins that could be expected to be found in vivo. Proteases, in addition to those tested, could also be expected to be found at inflammatory sites and may have similar effects. However, recent studies from our own laboratory have provided additional evidence supporting the biologic relevance of the in vitro observations reported in this communication (32). Using a sensitive immunoblot system, transferrin cleavage products were detected in 21 out of 22 bronchoalveolar lavage samples from $P$. aeruginosa-infected cystic fibrosis patients and 5 out of $13 \mathrm{BAL}$ samples from non-cystic fibrosis individuals with $P$. aeruginosa pulmonary infections. The presence of transferrin degradation products in airways does not appear to reflect a normal physiologic process as no such products were detected in healthy controls $(n=8)$. The ability of these transferrin cleavage products to catalyze -OH formation and cause tissue injury was not assessed in this study, but based on the present in vitro studies it is likely that these chelates are able to act as $\cdot \mathrm{OH}$ catalysts and could potentially contribute to $P$. aeruginosa-associated tissue injury.

In summary, we have obtained in vitro evidence that protease-cleaved Fe-transferrin augments oxidant-mediated endothelial cell injury via formation of the $\cdot \mathrm{OH}$ or another iron-dependent oxidant. This process may contribute to $P$. aeruginosaassociated microvascular lung injury. Furthermore, the findings with PPE-cleaved Fe-transferrin in particular suggest that any condition which leads to an increase in PMN elastase also has the capacity to generate these catalytic Fe-transferrin products. Thus, it seems that $\cdot \mathrm{OH}$ generation resulting from the cleavage of Fe-transferrin may contribute to other types of inflammatory microvascular injury characterized by increased proteolytic activity. Further investigations into the role of transferrin cleavage as a contribution to inflammatory tissue injury in vivo are indicated.

\section{Acknowledgments}

We thank Dr. Garry Buettner of the University of Iowa EPR Facility for his assistance with the spin trapping studies, Mary Lou Booth and Greg Aylsworth of the laboratory of Dr. D. Michael Shasby for their cell culture work, Dr. Charles Cox for providing the PAE, and Sherry Flanagan for her secretarial assistance in preparation of the manuscript.

This work was supported in part by awards from the Veterans Affairs Research Service, National Institutes of Health grants HL-44275, AI28412, and AI-34954, and an American Heart Association Grant in Aid. This work was performed in part during the tenure of Dr. Britigan as an Established Investigator of the American Heart Association. Dr. Miller is supported as an Interdisciplinary Cardiovascular Research Fellow (National Institutes of Health grant HL-07121).

\section{References}

1. Fick, R. B., Jr. 1989. Pathogenesis of the Pseudomonas lung lesion in cystic fibrosis. Chest. 96:158-164.

2. Pier, G. B. 1985. Pulmonary disease associated with Pseudomonas aeruginosa in cystic fibrosis. Current status of the host bacterium interaction. J. Infect. Dis. 151:515-580.

3. Suter, S., O. B. Schaad, L. Roux, U. E. Nydegger, and F. A. Waldvogel. 1984. Granulocyte neutral proteases and Pseudomonas elastase as possible causes of airway damage in patients with cystic fibrosis. J. Infect. Dis. 149:523-531.

4. Dunn, M. M., M. Dunne, and D. W. Kamp. 1990. Polymorphonuclear leukocyte- and Pseudomonas aeruginosa-induced damage to a human pulmonary epithelial cell line. J. Infect. Dis. 162:172-177.

5. Mohammed, J. R., B. S. Mohammed, L. J. Pawluk, D. M. Bucci, N. R. Baker, and W. B. Davis. 1988. Purification and cytotoxic potential of myeloperoxidase in cystic fibrosis sputum. J. Lab. Clin. Med. 112:711-720.

6. Holder, I. A. 1983. Experimental studies of the pathogenesis of infections due to Pseudomonas aeruginosa: effect of treatment with protease inhibitors. Rev. Infect. Dis. 5:S914-S921.

7. Kreger, A. S. 1983. Pathogenesis of Pseudomonas aeruginosa ocular disease. Rev. Infect. Dis. 5:S931-S935.

8. Wretlind, B., and O. R. Pavlovskis. 1983. Pseudomonas elastase and its role in pseudomonas infections. Rev. Infect. Dis. 5:S998-S1004.

9. Sibille, Y., and H. Y. Reynolds. 1990. Macrophages and polymorphonuclear neutrophils in lung defense and injury. Am. Rev. Respir. Dis. 141:471-501.

10. Cross, C. E., B. Halliwell, E. T. Borish, W. A. Pryor, R. L. Saul, J. M. McCord, and D. Harman. 1987. Oxygen radicals and human disease. Ann. Intern. Med. 107:526-545.

11. Britigan, B. E., G. T. Rasmussen, and C. D. Cox. 1994. The pseudomonas siderophore pyochelin enhances neutrophil-mediated endothelial cell injury. Am. J. Physiol. (Lung Cell. Mol. Physiol.) 266:L192-L198.

12. Ward, P. A. 1991. Mechanisms of endothelial cell injury. J. Lab. Clin. Med. 118:421-426.

13. Britigan, B. E., G. M. Rosen, Y. Chai, and M. S. Cohen. 1986. Do human neutrophils make hydroxyl radical? Detection of free radicals generated by human neutrophils activated with a soluble or particulate stimulus using electron paramagnetic resonance spectrometry. J. Biol. Chem. 261:4426-4431.

14. Halliwell, B., and J. M. C. Gutteridge. 1986. Oxygen free radicals and iron in relation to biology and medicine: some problems and concepts. Arch. Biochem. Biophys. 246:501-514.

15. Ramos, C. L., S. Pou, B. E. Britigan, M. S. Cohen, and G. M. Rosen. 1992. Spin trapping evidence for myeloperoxidase-dependent hydroxyl radical formation by human neutrophils and monocytes. J. Biol. Chem. 267:8307-8312.

16. Bullen, J. J., H. J. Rogers, and E. Griffiths. 1978. Role of iron in bacterial infection. Curr. Top. Microbiol. Immunol. 80:1-35.

17. Legrand, D., J. Mazurier, J. Montreuil, and G. Spik. 1988. Structure and spatial conformation of the iron-binding sites of transferrins. Biochimie (Paris). 70:1185-1195.

18. Masson, P. L., J. F. Heremans, and C. H. Dive. 1966. Studies on lactoferrin, an iron-binding protein common to many external secretions. Clin. Chim. Acta. 14:735-739.

19. Aruoma, O. I., and B. Halliwell. 1987. Superoxide-dependent and ascorbate-dependent formation of hydroxyl radicals from hydrogen peroxide in the presence of iron are lactoferrin and transferrin promoters of hydroxyl-radical generation? Biochem. J. 241:273-278.

20. Winterbourn, C. C. 1983. Lactoferrin-catalyzed hydroxyl radical production: additional requirements for a chelating agent. Biochem. J. 210:15-19.

21. Baldwin, D. A., E. R. Jenny, and P. Aisen. 1984. The effect of human serum transferrin and milk lactoferrin on hydroxyl radical formation from superoxide and hydrogen peroxide. J. Biol. Chem. 259:13391-13394.

22. Buettner, G. R. 1987. The reaction of superoxide, formate radical, and hydrated electron with transferrin and its model compound, $\mathrm{Fe}$ (III)-eyhylenediamine- $N, N^{\prime}$-bis [2-(2-hydroxyphenyl) acetic acid] as studied by pulse radiolysis. J. Biol. Chem. 262:11995-11998.

23. Gutteridge, J. M. C., S. K. Paterson, A. W. Segal, and B. Halliwell. 1981 Inhibition of lipid peroxidation by the iron-binding protein lactoferrin. Biochem. J. 199:259-261.

24. Ward, P. A., G. O. Till, R. Kunkel, and C. Beauchamp. 1983. Evidence for the role of hydroxyl radical in complement and neutrophil-dependent tissue injury. J. Clin. Invest. 72:789-801.

25. Doring, G., M. Pfestorf, K. Botzenhart, and M. A. Abdallah. 1988. Impact of proteases on iron uptake of Pseudomonas aeruginosa pyoverdin from transferrin and lactoferrin. Infect. Immun. 56:291-293.

26. Brines, R. D., and J. H. Brock. 1983. The effect of trypsin and chymotrypsin on the in vitro antimicrobial and iron-binding properties of lactoferrin in human milk and bovine colostrum: unusual resistance of human apolactoferrin to proteolytic digestion. Biochim. Biophys. Acta. 759:229-235.

27. Line, W. F., D. A. Sly, and A. Bezkorovainy. 1976. Limited cleavage of human lactoferrin with pepsin. Int. J. Biochem. 9:203-208.

28. Bluard-Deconinck, J., J. Williams, R. W. Evans, J. van Snick, P. A. Osinski, and P. L. Masson. 1978. Iron-binding fragments from the N-terminal and C-terminal regions of human lactoferrin. Biochem. J. 171:321-327.

29. Evans, R. W., and J. Williams. 1978. Studies of the binding of different iron donors to human serum transferrin and isolation of iron-binding fragments from the N- and C-terminal regions of the protein. Biochem. J. 173:543-552.

30. Esparza, I., and J. H. Brock. 1980. The effect of trypsin digestion on the structure and iron-donating properties of transferrins from several species. Biochim. Biophys. Acta. 622:297-307.

31. Britigan, B. E., and B. L. Edeker. 1991. Pseudomonas and neutrophil products modify transferrin and lactoferrin to create conditions that favor hydroxyl radical formation. J. Clin. Invest. 88:1092-1102. 
32. Britigan, B. E., M. B. Hayek, B. N. Doebbeling, and R. B. Fick, Jr. 1993. Transferrin and lactoferrin undergo proteolytic cleavage in the Pseudomonas aeruginosa-infected lungs of patients with cystic fibrosis. Infect. Immun. 61:50495055.

33. Bodey, G. P., R. Bolivar, V. Fainstein, and L. Jadeja. 1983. Infections caused by Pseudomonas aeruginosa. Rev. Infect. Dis. 5:279-313.

34. Fick, R. B., Jr., and J. S. Hata. 1989. Pathogenetic mechanisms in lung disease caused by Pseudomonas aeruginosa. Chest. 95:206S-213S.

35. Bedrossian, C. W. M., S. D. Greenberg, D. B. Singer, J. J. Hansen, and H. S. Rosenberg. 1976. The lung in cystic fibrosis. A quantitative study including prevalence of pathologic findings among different age groups. Hum. Pathol. 7:195-204.

36. Cash, H. A., D. E. Woods, B. McCullough, W. G. Johanson, and J. A. Bass. 1979. A rat model of chronic respiratory infection with Pseudomonas aeruginosa. Am. Rev. Respir. Dis. 119:453-459.

37. Heffner, J. E., and J. E. Repine. 1989. Pulmonary strategies of antioxidant defense. Am. Rev. Respir. Dis. 140:531-554.

38. Laemmli, U. K. 1970. Cleavage of structural proteins during assembly of the head of bacteriophage $\mathrm{T}_{4}$. Nature (Lond.). 227:680-685.

39. Britigan, B. E., T. L. Roeder, and D. M. Shasby. 1992. Insight into the nature and site of oxygen-centered free radical generation by endothelial cell monolayers using a novel spin trapping technique. Blood. 79:699-707.

40. Busch, C., P. A. Cancilla, L. E. DeBault, J. C. Goldsmith, and W. G Owen. 1982. Use of endothelium cultured on microcarriers as a model for the microcirculation. Lab. Invest. 47:498-504.

41. Borregaard, N., J. M. Heiple, E. R. Simons, and R. A. Clark. 1983 Subcellular localization of the $b$-cytochrome component of the human neutrophil microbicidal oxidase. Translocation during activation. J. Cell Biol. 97:52-61.

42. Greenwald, R. A., S. W. Rush, S. A. Mark, and Z. Weitz. 1989. Conversion of superoxide generated by polymorphonuclear leukocytes to hydroxyl radical: a direct spectrophotometric detection system based on degradation of deoxyribose. Free Radical. Biol. \& Med. 6:385-392.

43. Halliwell, B., and J. M. C. Gutteridge. 1981. Formation of a thiobarbituric acid-reactive substance from deoxyribose in the presence of iron salts. The role of superoxide and hydroxyl radicals. FEBS (Fed. Eur. Biochem. Soc.) Lett. 128:347-351.

44. Russell, R. M. 1992. Nutritional assessment. In Cecil Textbook of Medicine. J. B. Wyngaarden, L. H. Smith, Jr., and J. C. Bennett, editors. W. B. Saunders Co., Philadelphia. 1154

45. Finkelstein, E., G. M. Rosen, and E. J. Rauckman. 1980. Spin trapping. Kinetics of the reaction of superoxide and hydroxyl radical with nitrones. J. Am. Chem. Soc. 102:4994-4999.

46. Suter, S., O. B. Schaad, H. Tegner, K. Ohlsson, D. Desgrandchamps, and F. A. Waldvogel. 1986. Levels of free granulocyte elastase in bronchial secretions from patients with cystic fibrosis. J. Infect. Dis. 153:902-909.

47. Amitani, R., R. Wilson, A. Rutman, R. Read, C. Ward, D. Burnett, R. A Stockley, and P. J. Cole. 1991. Effects of human neutrophil elastase and Pseudomonas aeruginosa proteinases on human respiratory epithelium. Am. J. Respir. Cell Mol. Biol. 4:26-32.

48. Doring, G., W. Goldstein, A. Roll, P. O. Schiotz, N. Hoiby, and K.
Botzenhart. 1985. Role of Pseudomonas aeruginosa exoenzymes in lung infections of patients with cystic fibrosis. Infect. Immun. 49:557-562.

49. Doring, G., H.-J. Obernesser, K. Botzenhart, B. Flehmig, N. Hoiby, and A. Hofmann. 1983. Proteases of Pseudomonas aeruginosa in patients with cystic fibrosis. J. Infect. Dis. 147:744-750.

50. Suter, S. 1989. The imbalance between granulocyte neutral proteases and antiproteases in bronchial secretions from patients with cystic fibrosis. Antibiot. Chemother. 42:158-168.

51. Stone, P. J., C. Franzblau, and H. M. Kagan. 1982. Proteolysis of insoluble elastin. Methods Enzymol. 82:588-592.

52. Pennington, J. P. 1990. Nosocomial respiratory infection. In Principles and Practice of Infectious Diseases. G. L. Mandell, R. G. Douglas, Jr., and J. E. Bennett, editors. Churchill Livingstone, New York. 2199-2205.

53. Stern, R. C., R. E. Wood, T. F. Boat, L. W. Matthews, A. S. Tucker, and C. F. Doershuk. 1978. Treatment and prognosis of massive hemoptysis in cystic fibrosis. Am. Rev. Respir. Dis. 117:825-828.

54. Cabelli, D. E., D. Allen, B. H. J. Bielski, and J. Holeman. 1988. The interaction between $\mathrm{Cu}(\mathrm{I})$ superoxide dismutase and hydrogen peroxide. J. Biol. Chem. 264:9967-9971.

55. Marriott, P. R., M. J. Perkins, and D. Griller. 1980. Spin trapping for hydroxyl in water: a kinetic evaluation of two popular traps. Can. J. Chem. 58:803-807.

56. Brieland, J. K., S. J. Clarke, S. Karmiol, S. H. Phan, and J. C. Fantone. 1992. Transferrin: a potential source of iron for oxygen free radical-mediated endothelial cell injury. Arch. Biochem. Biophys. 294:265-270.

57. Fick, R. B., Jr., G. P. Naegel, S. U. Squier, R. E. Wood, J. B. L. Gee, and H. Y. Reynolds. 1984. Proteins of the cystic fibrosis respiratory tract: fragmented immunoglobulin $\mathbf{G}$ opsonic antibody causing defective opsonophagocytosis. $J$. Clin. Invest. 74:236-248.

58. Bruce, M. C., L. Poncz, J. D. Klinger, R. C. Stern, J. F. Tomashefski, Jr., and D. G. Dearborn. 1985. Biochemical and pathologic evidence for proteolytic destruction of lung connective tissue in cystic fibrosis. Am. Rev. Respir. Dis. 132:529-535.

59. Goldstein, W., and G. Doring. 1986. Lysosomal enzymes from polymorphonuclear leukocytes and proteinase inhibitors in patients with cystic fibrosis. Am. Rev. Respir. Dis. 134:49-56.

60. Jackson, A. H., S. L. Hill, S. C. Afford, and R. A. Stockley. 1984. Sputum sol-phase proteases and elastase activity in patients with cystic fibrosis. Eur. J. Respir. Dis. 65:114-124.

61. Meyer, K. C., J. R. Lewandoski, J. J. Zimmerman, D. Nunley, W. J. Calhoun, and G. A. Dopico. 1991. Human neutrophil elastase and elastase/alpha ${ }_{1}$ antiprotease complex in cystic fibrosis: comparison with interstitial lung disease and evaluation of the effect of intravenously administered antibiotic therapy. Am. Rev. Respir. Dis. 144:580-585.

62. Reynolds, H. Y. 1987. Bronchoalveolar lavage. Am. Rev. Respir. Dis. 135:250-263.

63. Reichart, E., P. Boerkmann, and F. Plenat. 1992. Parenteral administration of trypsin triggers lung emphysema. Eur. Respir. J. 5:810-814.

64. Hatanaka, M., and K. Tsuboi. 1991. Initiation of wound healing by proteinases released from damaged cells. Int. J. Tissue React. 13:249-255. 